\title{
CARBON TO NITROGEN RATIO AND NITROGENOUS WASTE ACCUMULATION IN THE INTENSIVE CATFISH (Clarias gariepinus) CULTURE
}

\author{
Bambang Gunadi"*\#, Enang Harris ${ }^{* *}$, Eddy Supriyono ${ }^{* * *}$, Sukenda ${ }^{* *}$, and Tatag Budiardi*) \\ ") Research Institute for Freshwater Fish Breeding and Aquaculture \\ ${ }^{*}$ Department of Aquaculture, Faculty of Fisheries and Marine Sciences, \\ Bogor Agricultural University, Darmaga, Bogor, Indonesia
}

(Received 2 February 2011 ; Accepted 5 April 2011 1)

\begin{abstract}
This experiment was carried out to determine the optimum $\mathrm{C} / \mathrm{N}$ ratio for heterotrophic bacteria (biofloc) growth in order to control nitrogenous waste accumulation in the catfish (Clarias gariepinus) culture. Twenty fish with an initial individual size of about $50 \mathrm{~g}$ were stocked in fiberglass tanks which were filled with $200 \mathrm{~L}$ of water. Fish were fed with commercial floating fish feed with a protein level of $31 \%-33 \%$ (manufacturer label). The daily feeding rate was $2.5 \%$ of the fish biomass. The inoculation of commercial Bacillus sp. isolates was applied in the first day of the experiment after fish stocking in order to obtain a bacterial density in water of $10^{6} \mathrm{cfu} / \mathrm{L}$. Molases was suplemented daily to the tanks to adjust $\mathrm{C} / \mathrm{N}$ ratio in water. Four $\mathrm{C} / \mathrm{N}$ ratios, i.e. 0,7 , 14 , and 21 , were applied as treatments in this experiment. The results showed that molasses suplementation up to $\mathrm{C} / \mathrm{N}$ ratio 14 to 21 were able to support the growth of heterotrophic bacteria and to inhibit the accumulation of total ammonia nitrogen (TAN) and nitrite in water therefore increase water quality for better growth of cultured catfish.
\end{abstract}

KEYWORDS: $\mathrm{C} / \mathrm{N}$ ratio, nitrogenous waste, heterotrophic bacteria, biofloc

\section{INTRODUCTION}

Most of the feed given to the fish will be excreted as nitrogenous metabolism waste. In general, $60 \%$ of nitrogen contained in the fish feed will be excreted as $\mathrm{NH}_{3}$, while $15 \%$ of feed nitrogen will be excreted into faeces and only $25 \%$ of feed nitrogen will be retained for fish growth. Simply, $75 \%$ of the nitrogen content in feed was potentially delivered to pond water as ammonia pollution. In the shrimp cultivation, this kind of pollution was amounted to $90 \%$ of feed nitrogen (Brune et al., 2003). This compound can diminish the productivity of fish culture and is the potential source of pollution to the surrounding environment. Controlling such waste is one of the important factor to achieve the sustainability of aquaculture production in the future (Bureau, 2004).

Wyk \& Avnimelech (2007) stated that as many as $70 \%-80 \%$ of nitrogen in the feed is converted into ammonia by direct excretion or through mineralization by bacteria. According to Avnimelech et al. (1992), 33\% of nitrogen contained in fish feed will be excreted by fish and can be recycled.

\# Corresponding author. Research Institute for Freshwater Fish Breeding and Aquaculture, Jl. Raya 2 Sukamandi, Subang 41256, West Java, Indonesia. Tel.: +62 260520500

E-mail address: bgunadi@rocketmail.com; bgunadi@dp.go.id 
Bacteria communities which accumulate in the aquaculture systems will form bacterial flocs. These flocs can be utilized as a source of feed for fish (Schryver et al., 2008; Crab et al., 2007). Microbes composition, morphological structure and nutritional value of biofloc for aquaculture is determined by various factors including the mixing intensity of water, dissolved oxygen levels in water, the type and amount of supply of organic material into the water, and water temperature and $\mathrm{pH}$ (Schryver et al., 2008). In order to get the best conversion rate of nutrients into bacterial biomass, Schneider et al. (2006) suggested that the hydraulic retention time should between 5-9 hours. At the retention time of 8 hours, the average bacterial biomass production reached $123.8 \mathrm{~g} \mathrm{VSS} / \mathrm{kg}$ feed with inorganic nitrogen conversion rate reached $90 \%$.

Ebeling et al. (2006) said that the nitrogen conversion processes in aquaculture systems that played an important role in the reduction of ammonia level consisted of three processes namely photoautotrophic processes by algae, bacterial autotrophic processes that converted ammonia to nitrate, and bacterial heterotrophic processes that converts ammonia directly into bacteria biomass. However, in the natural system, there were no pure photoautotrophic, bacterial heterotrophic nor bacterial autotrophic (Wyk \& Avnimelech, 2007).

According to Schneider et al. (2005), the biochemical processes in pond water were mainly work on the soluble fish waste compounds. The particulate waste was often discharged in large quantities as unutilized nutrients. Heterotrophic bacteria were able to convert these kind of nutrients to bacterial biomass which are potential as fish feed ingredients. On the feeding trial with pelletized feed of $41 \%$ protein content, the supplementation of sodium acetate resulted in bacterial biomass production as 55-125 g VSS $/ \mathrm{kg}$ feed, equivalent to 0.2-0.5 g VSS/g carbon (Schneider et al., 2006). Theoretically, $1 \mathrm{~g}$ of ammonium is required to convert $20 \mathrm{~g}$ of carbohydrate (Avnimelech \& Wyk, 2007).

Montoya \& Velasco (2000) said that the ammonia excreted by fish will form an equilibrium with ammonium ions in the water. In the natural condition, ammonia in the form of ammonium ions will be converted into nitrite and subsequently into nitrate under nitrification processes by chemoautotrophic bacteria. In the presence of sufficiently organic materials, heterotrophic microbial processes will be the dominant bacterial process which convert ammonium into bacteria biomass more quickly than autotrophic bacteria. The heterotrophic bacteria are able to absorb up to $50 \%$ of the amount of dissolved ammonium in the water.

The production efficiency of heterotrophic bacteria was much higher than the nitrifying bacteria, i.e. 25-100 times than that of Nitrosomonas sp. and 10-33 times than that of Nitrobacter sp. (Montoya \& Velasco, 2000). According to Brune et al. (2003), the process of biosynthesis of heterotrophic bacteria took place more quickly than the process of biosynthesis of algae or the process of bacterial nitrification. The regeneration times of the heterotrophic bacteria are about 10 hours compare with 24-48 hours of nitrification bacteria. Algae and nitrification bacteria had similar growth rate, however the production coefficient of algae was almost 57 times higher than that of the nitrifying bacteria, i.e. $11.4 \mathrm{~g}$ algae/ $\mathrm{g} \mathrm{N}$ in compare to $0.2 \mathrm{~g}$ bacteria/g N. McGraw (2002) stated that in addition to having fastergrowth, heterotrophic bacteria was good source for fish feed.

This experiment was conducted to analyze the optimum ratio of carbon to nitrogen (the $\mathrm{C} / \mathrm{N}$ ratio) to support the growth of heterotrophic bacteria (biofloc) in order to control the accumulation of nitrogenous waste in the intensive catfish culture.

\section{MATERIALS AND METHODS}

\section{Fish Tanks}

The 250- $\mathrm{L}$ size fiberglass tanks were used in this experiment. The tanks were filled with 200 liters of water. The aeration equipments were installed in each tanks to ensure that the dissolved oxygen level in water was not drop less than $2 \mathrm{mg} / \mathrm{L}$ (Schneider et al., 2006). The tanks were covered with dark plastic to minimize phytoplankton growth due to the availability of light.

The disinfectant of chlorine was applied at a dose of $5 \mathrm{mg} / \mathrm{L}$. It was conducted three days before fish stocking to avoid undesired microbes (bacteria) in the water. After the disinfectant was re-neutralized, i.e. about three days after chlorine application, the fish were stocked into the tanks. 
Inoculation of commercial bacteria isolate of Bacillus sp. was carried out once at the first day of feeding to get a bacterial density in tanks water of about $10^{6} \mathrm{cfu} / \mathrm{mL}$.

\section{Fish Stocking}

Catfish (Clarias gariepinus) fingerlings with average weight of $50 \mathrm{~g}$ were used in this experiment. The stocking densities were 20 fish per tank, equivalent to 100 fish per $\mathrm{m}^{3}$ or $5 \mathrm{~kg}$ per $\mathrm{m}^{3}$. In the adaptation period, fish were fasted for 24 hours before stocked.

Fish were fed with a commercial floating pelletized feed with crude protein content of 31\%-33\% (manufacturer label). The feed was given at a daily rate of $2.5 \%$ of the fish biomass and was applied three times a day started on the first day of fish stocking.

\section{Treatments}

The experiment was designed according to completely randomized design with four treatments and three replicates. Four treatments applied in this experiment were as follows:

1. No application of molasses (called $\mathrm{C} / \mathrm{N}=0$ )

2. The application of molasses at ratio of $7 \mathrm{C}$ : $1 \mathrm{~N}($ called $\mathrm{C} / \mathrm{N}=7)$

3. The application of molasses at ratio of of 14C $: 1 \mathrm{~N}$ (called $\mathrm{C} / \mathrm{N}=14$ )

4. The application of molasses at ratio of of 21C: $1 \mathrm{~N}($ called $\mathrm{C} / \mathrm{N}=21)$

The application of molasses was taken everyday by diluting it into tanks water. The amount of required molases was calculated according to the concentration of carbon and nitrogen in the water and feces. The previous studies using floating pellets with protein con- tent of $31.85 \%$ dry weight gave the following results:

- Protein content in the feces amounted to $31.65 \%$ dry weight, therefore nitrogen $(\mathrm{N})$ concentration in the feces was $5.06 \%$. This value was equivalent to $0.86 \%$ of wet weight of feed.

- Carbohydrate levels in the feces amounted to $42.24 \%$, so that levels of carbon (C) in the feces amounted to $16.90 \%$. With the digestibility of feed of $83.16 \%$, then the amount of feces produced was $16.84 \%$ of wet weight of feed. Thus, the amount of carbon (C) in the feces was equivalent to $2.85 \%$ of wet weight of feed.

- The total ammonia (TAN) supply in water was $0.20 \%$ of wet weight of feed.

With above assumptions, the amount of molasses which were required to add daily was calculated as listed in Table 1.

\section{Floc Properties and Water Quality Parameters}

Samplings to observe floc properties and water quality were carried out every two days for bacteria population in form of volatile suspended solids (VSS), floc volume, concentration of ammonia, nitrite, nitrate, dissolved oxygen, and $\mathrm{pH}$ level of the tanks water. The VSS was determined gravimetrically after drying at $105^{\circ} \mathrm{C}$ and burning at $550^{\circ} \mathrm{C}$ of GF/C-filtered tank water (Method 2540 E; APHA, 2005). The level of dissolved oxygen and $\mathrm{pH}$ of water was measured by the Water Quality Checker. The concentration of ammonia, nitrite, and nitrate were measured by HACH DR2 800 Spectrophotometer following the Nessler method $(\mathrm{HACH}$, $8038)$, cadmium reduction method $(\mathrm{HACH}$, 8039) and Diazotization method (HACH, 8507),

Table 1. The addition of molasses in each treatment to obtain the expected $\mathrm{C} / \mathrm{N}$ ratio

\begin{tabular}{lcccc}
\hline $\begin{array}{c}\text { Treatments } \\
\text { (The expected of } \\
\text { C/N ratio) }\end{array}$ & $\begin{array}{c}\text { Total feed } \\
(\mathbf{g})\end{array}$ & $\begin{array}{c}\text { The amount of } \\
\text { molasses addition } \\
(\mathbf{g})\end{array}$ & $\begin{array}{c}\text { Percentage of } \\
\text { molasses from feed } \\
(\%)\end{array}$ & Note \\
\hline $\mathrm{C} / \mathrm{N}=0$ (without & 36.15 & 0 & 0 & $\begin{array}{l}\text { C/N ratio obtained } \\
\text { is } 2.69 \\
\text { molasses) }\end{array}$ \\
$\mathrm{C} / \mathrm{N}=7(7 \mathrm{C}: 1 \mathrm{~N})$ & 36.15 & 6.60 & 18.26 & \\
$\mathrm{C} / \mathrm{N}=14(14 \mathrm{C}: 1 \mathrm{~N})$ & 36.15 & 17.31 & 47.89 & \\
$\mathrm{C} / \mathrm{N}=21(21 \mathrm{C}: 1 \mathrm{~N})$ & 36.30 & 28.14 & 77.52 & \\
\hline
\end{tabular}


respectively ( $\mathrm{HACH}, 2005)$. Floc volume was measured by settling $1,000 \mathrm{~mL}$ of water into Imhoff cones for 30 minutes.

Growth of fish was measured by weighing the total biomass of fish at the beginning and end of the experiment. The experiment was carried out for 8 days.

\section{Data Analysis}

The results of the measured parameters were plotted graphically to evaluate their dynamics from the beginning to the end of the experiment. The developments of bacteria population were then correlated with the concentration of ammonia, nitrite, and nitrate. Some of value of measured parameters at the end of the experiment were analyzed by analysis of variance (ANOVA) to determine their significance differences among the treatments.

\section{RESULTS AND DISCUSSION}

\section{Bacteria Population}

The population of bacteria in the form of volatile suspended solids (VSS) showed a tendency to increase during 8 days of observation (Figure 1). The average of VSS value at the end of experiment ranged from $0.235 \mathrm{mg} / \mathrm{L}$ in the $\mathrm{C} / \mathrm{N}=7$ treatment to $0.388 \mathrm{mg} / \mathrm{L}$ in the $\mathrm{C} /$ $\mathrm{N}=14$ treatment. Overall, the VSS concentration at the end of the experiment was not significantly different between treatments $(P>$ 0.05).
However, there were indications that the higher $\mathrm{C} / \mathrm{N}$ ratio in the water, the higher bacterial growth. This was more clearly illustrated in the regression relationship between bacterial populations and the $\mathrm{C} / \mathrm{N}$ ratio (Figure 2 ). Despite the relatively low regression coefficient value, i.e. value of $R^{2}=0.5957$, there was a tendency that the higher $\mathrm{C} / \mathrm{N}$ ratio caused higher growth of bacteria population.

Increasing $\mathrm{C} / \mathrm{N}$ ratio in fish pond water can be conducted by adding carbon source, such as molasses, wheat flour, sugar, sodium acetate, and other materials with high carbohydrate content. Schneider et al. (2006), found that carbon supplementation stimulated bacteria production in aquaculture systems. The addition of sodium acetate as carbon source of $8 \mathrm{~g} / \mathrm{L}$ enhanced the production of crude protein up to $112 \mathrm{~g}$ protein $/ \mathrm{kg}$ feed, amounted an increment of $50 \%$ of the ordinary system. On fish feeding with $41 \%$ protein content, the addition of sodium acetate could support bacterial production for 55-125 g VSS $/ \mathrm{kg}$ feed, equivalent to $0.2-0.5 \mathrm{~g} \mathrm{VSS} / \mathrm{g}$ carbon.

\section{Total Ammonia Nitrogen (TAN)}

Ammonia is the main metabolic wastes of fish and frequently becomes a problem in fish farming. This compound should be kept in a very low level. Converting ammonia into bacterial biomass is a strategy to achieve this condition. The addition of carbon source to increase the $\mathrm{C} / \mathrm{N}$ ratio in water is expected to support optimum bacterial growth, therefore

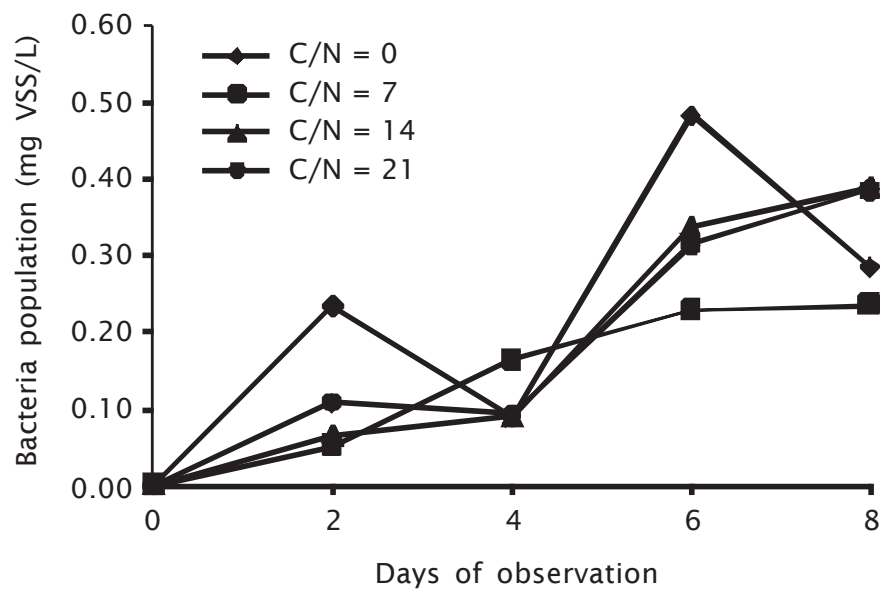

Figure 1. Bacteria population in the form of VSS in the fish culture tanks for eight days of observation 


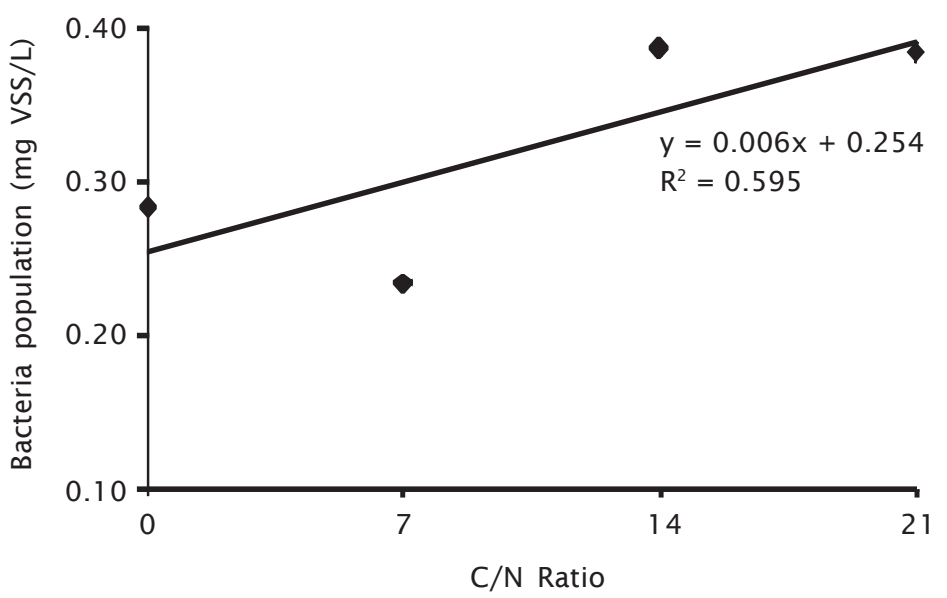

Figure 2. Regression relationship between $\mathrm{C} / \mathrm{N}$ ratio and bacteria population after eight days of catfish culture

high rate conversion of ammonia into bacterial biomass. Theoretically, $20 \mathrm{~g}$ carbohydrate is required to convert $1 \mathrm{~g}$ of ammonium (Avnimelech \& Wyk, 2007).

In this study, increasing $\mathrm{C} / \mathrm{N}$ ratio up to 14 to 21 was able to control total ammonia level in water until the fourth day (Figure 3). During this period, the increment of ammonia levels in the treatment of $\mathrm{C} / \mathrm{N}=14$ and $\mathrm{C} / \mathrm{N}=$ 21 , i.e., $0.32 \pm 0.14$ and $0.13 \pm 0.15 \mathrm{mg} / \mathrm{L}$, respectively, was significantly $(\mathrm{P}<0.05)$ lower than that of the treatment of $\mathrm{C} / \mathrm{N}=0$ and $\mathrm{C} / \mathrm{N}=$ 7, i.e., $1.19 \pm 0.48$ and $0.62 \pm 0,09 \mathrm{mg} / \mathrm{L}$, respectively. According to Montoya \& Velasco
(2000), in the presence of organic materials, microbial processes that take place in the water will be dominated by heterotrophic bacteria and absorbed ammonium into bacteria biomass more rapidly than with autotrophic nitrifying bacteria. Heterotrophic bacteria were able to absorb up to $50 \%$ of the dissolved ammonium in water.

After day-4, total ammonia levels in all treatments increased in a range of $2.01 \pm 1.02$ $\mathrm{mg} / \mathrm{L}$ in treatment of $\mathrm{C} / \mathrm{N}=14$ to $2.47 \pm 0.49$ $\mathrm{mg} / \mathrm{L}$ in treatment of $\mathrm{C} / \mathrm{N}=0$. Overall, the increment of TAN levels increase during the eight days ranged from $2.01 \pm 1.02 \mathrm{mg} / \mathrm{L}$ in

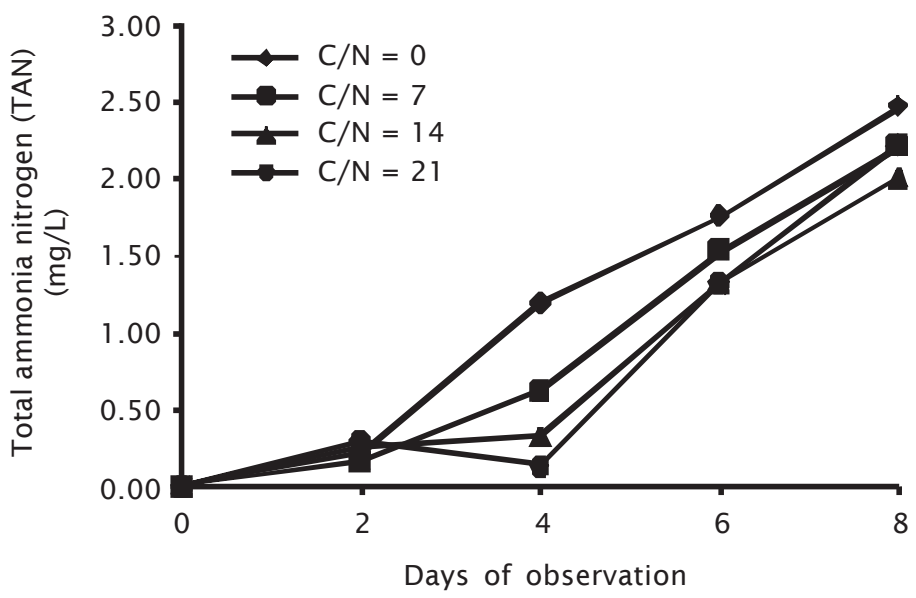

Figure 3. The dynamics of the Total Ammonia Nitrogen (TAN) in catfish culture during eight days of observation 
treatment $\mathrm{C} / \mathrm{N}=14$ to $2.55 \pm 0.49 \mathrm{mg} / \mathrm{L}$ on treatment $\mathrm{C} / \mathrm{N}=0$, and was not significantly different between treatments $(P>0.05)$. The fact that ammonia levels increased, especially after the day-4, showed that the growth of heterotrophic bacteria was not able to offset the accumulation of total ammonia in water.

Four main streams of $\mathrm{N}$ lost in fish ponds were fish harvesting (31.5\%), denitrification (17.4\%), ammonia volatilization (12.5\%), and $\mathrm{N}$ accumulation in the pond bottom sediment (22.6\%). Average nitrification rate was $70 \mathrm{mg}$ $\mathrm{N} / \mathrm{m}^{2}$ per day whereas denitrification rate was $38 \mathrm{mg} \mathrm{N} / \mathrm{m}^{2}$ per day. Phytoplankton absorb nitrate $\left(\mathrm{NO}_{3}-\mathrm{N}\right)$ at a rate of $24 \mathrm{mg} \mathrm{N} / \mathrm{m}^{2}$ per day. Meanwhile, the average mineralization rate of feed nitrogen into ammonia was $59 \mathrm{mg} \mathrm{N} / \mathrm{m}^{2}$ per day (Gross et al., 2000).

\section{Nitrite}

The compound of nitrite was the result of the first stage nitrification process which was carried out mainly by Nitrosomonas sp. bacteria. In the natural waters with low $\mathrm{C} / \mathrm{N}$ ratio, the process of ammonia breakdown was dominated by this bacterial nitrification process. On the contrary, in a heterotrophic system where the $\mathrm{C} / \mathrm{N}$ ratio was elevated through addition of carbon sources, the nitrification was hampered by a faster-running heterotrophic process (Montoya \& Vilasco, 2000).

This study revealed those phenomenon. Treatments with lower $\mathrm{C} / \mathrm{N}$ ratio had higher nitrite level than treatments with higher $\mathrm{C} / \mathrm{N}$ ratio (Figure 4). On the eighth day of treatment, the lowest nitrite level was observed at the treatment of $\mathrm{C} / \mathrm{N}=14$, i.e., $0.0131 \pm 0.0015$ $\mathrm{mg} / \mathrm{L}$, while the highest nitrite level was obtained in the control treatment $(\mathrm{C} / \mathrm{N}=0)$, i.e., $0.0459 \pm 0.0132 \mathrm{mg} / \mathrm{L}$.

In general, the lower nitrite concentration were found in the higher $\mathrm{C} / \mathrm{N}$ ratio treatments $(\mathrm{C} / \mathrm{N}=14$ and $\mathrm{C} / \mathrm{N}=21)$, whereas the higher concentrations were observed in the lower $\mathrm{C} / \mathrm{N}$ ratio treatments $(\mathrm{C} / \mathrm{N}=0$ and $\mathrm{C} / \mathrm{N}=7)$. In the high $\mathrm{C} / \mathrm{N}$ ratio nitrification process took place more slowly than heterotrophic bacterial process of ammonia conversion. In addition, the lower $\mathrm{C} / \mathrm{N}$ ratio treatments had relatively normal nitrification process.

\section{Nitrate}

Nitrate concentration in the treatment with molasses addition $(\mathrm{C} / \mathrm{N}=7, \mathrm{C} / \mathrm{N}=14$, and $\mathrm{C} / \mathrm{N}$ $=21$ ) showed an increment from the beginning until the day- 6 and then decreased afterwards. In the other hand, in treatment without carbon supplementation $(\mathrm{C} / \mathrm{N}=0)$ nitrate concentration increased steadily from the beginning until day- 8 (Figure 5). This indicated that the second stage of nitrification process which converted nitrite into nitrate ran in the treatment of $\mathrm{C} / \mathrm{N}=0$ throughout the period of observation. In the other treatments nitrification process of nitrate formation occured mainly during the initial four days.

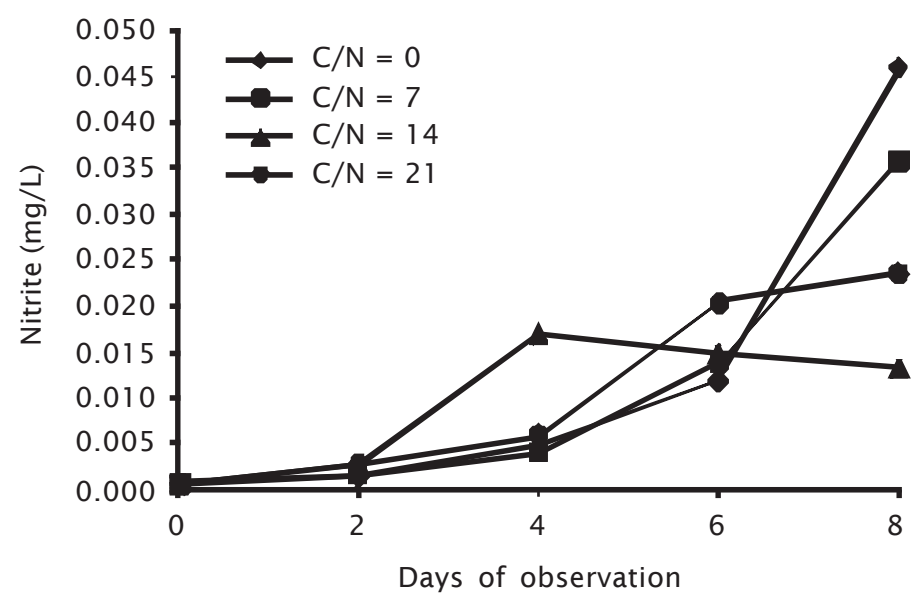

Figure 4. Performance of nitrite in water media maintenance catfish during the eight days of observation 


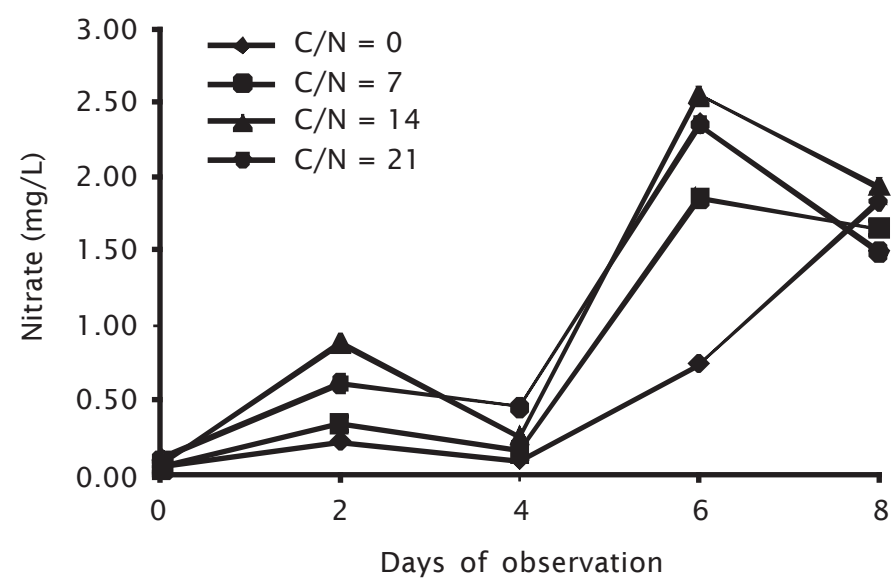

Figure 5. Performance of nitrate levels in the catfish culture water during the eight days of observation

\section{Dissolved Oxygen}

Dissolved oxygen levels in all treatments declined sharply during the first two days and then were relatively stable in a range of 1-2 $\mathrm{mg} / \mathrm{L}$ (Figure 6). Additional aeration to each tanks was not enough to maintain dissolved oxygen excess of minimum level for optimal growth of heterotrophic bacteria. According to Schneider et al. (2006), minimum dissolved oxygen level of $2 \mathrm{mg} / \mathrm{L}$ was required to support optimum bacterial heterotrophic processes.

Most of aquatic organisms need optimum dissolved oxygen levels to meet their respira- tion requirement. As organisms test, this study utilized catfish which had ability to consume oxygen directly from air. Their capability lead to the fact that catfish were not bother by the low oxygen level in water, as happened in this study.

\section{Water $\mathbf{p H}$}

There was a different pattern of performance of water $\mathrm{pH}$ during observation in the catfish culture with heterotrophic system through the addition of molasses as carbon source. Water $\mathrm{pH}$ in the treatment of $\mathrm{C} / \mathrm{N}=0$ and $\mathrm{C} / \mathrm{N}=7$ increased from the beginning to

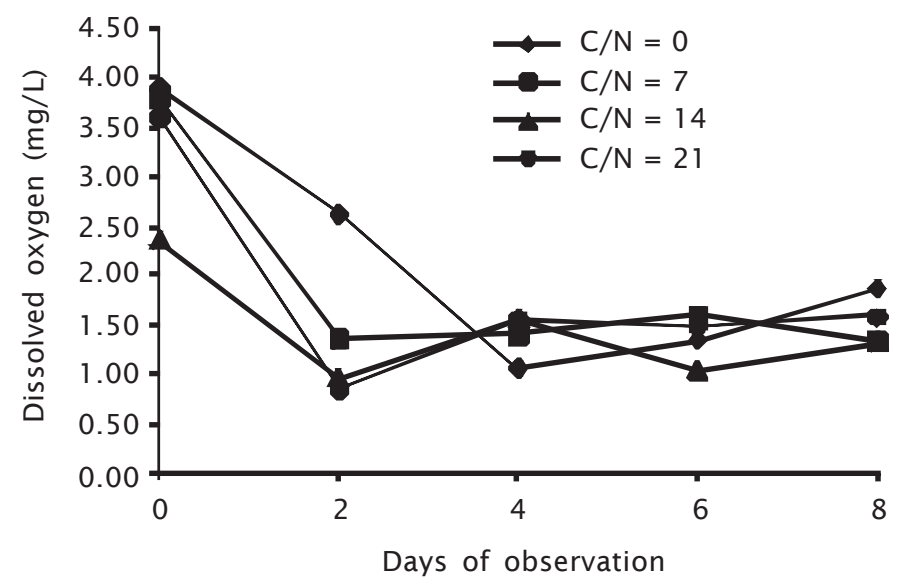

Figure 6. Performance of dissolved oxygen levels in water media maintenance catfish during the eight days of observation 


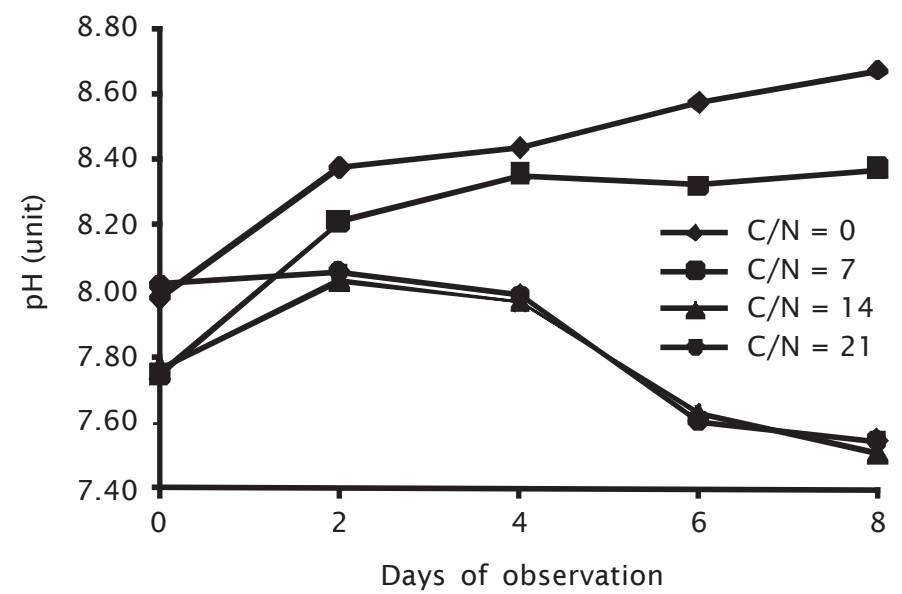

Figure 7. Dynamics of water $\mathrm{pH}$ value of catfish tanks during the eight days observation

the end of the observation. In contrast, in the treatment with higher $\mathrm{C} / \mathrm{N}$ ratio $(\mathrm{C} / \mathrm{N}=14$ and $\mathrm{C} / \mathrm{N}=21$ ), water $\mathrm{pH}$ declined until the end of fish culture (Figure 7).

The decrease of water $\mathrm{pH}$ in the heterotrophic treatments $(\mathrm{C} / \mathrm{N}=14$ and $\mathrm{C} / \mathrm{N}=21)$ was suspected mainly deal with the process of nitrification by Nitrosomonas bacteria which produced nitrite. According to Brune et al. (2003), each conversion of one gram of nitrogen would require alkalinity equivalent to $7.1 \mathrm{~g} \mathrm{CaCO}_{3}$. The decrease of alkalinity and increase of $\mathrm{H}^{+}$ions will decline $\mathrm{pH}$. On the other hand, increasing $\mathrm{pH}$ was mainly associated with the presence of $\mathrm{CO}_{2}$ as a result of respiration of biota in water.

In general, $\mathrm{pH}$ values measured in this study were in the optimum range for most fish and other aquatic biota, i.e., 6.5 to 8.5 (Svobodova et al., 1993).

\section{Floc Volume}

Bacteria communities in aquaculture systems will form a floc which comprises various microorganisms including algae, protozoan, and bacteria themselves. The observation of the floc volume showed that generally the floc grew until the sixth day and then declined afterwards. The treatment of $\mathrm{C} / \mathrm{N}=14$ gave the highest growth of floc which reached a peak of $52.67 \mathrm{~mL} / \mathrm{L}$ at day- 6 . The treatment of $\mathrm{C} / \mathrm{N}=$ 21 provided the lowest floc development (Figure 8).
Microbial composition, morphological structure, and nutritional value of aquacultural biofloc was determined by various factors including the intensity of water mixing, dissolved oxygen levels in water, the type and amount of organic material supply, temperature, and pH of water (Schryver et al., 2008).

\section{Fish Growth}

The growth of catfish during eight days of observation are provided in Appendix 1. The higher $\mathrm{C} / \mathrm{N}$ ratio caused higher growth of catfish. This fact was related to the lower level of total ammonia and nitrite in the water. There was an exception that fish growth in the treatment of $\mathrm{C} / \mathrm{N}=0$ was $8.36( \pm 3.34) \%$, higher than those in treatment $\mathrm{C} / \mathrm{N}=7$ and $\mathrm{C} / \mathrm{N}=14$, i.e. $7.28( \pm 2.35) \%$ and $7.83( \pm 2.28) \%$, respectively.

The addition of molasses as a carbon source to increase $\mathrm{C} / \mathrm{N}$ ratio in the water seemed to be able to maintain water quality in better conditions, especially in inhibiting the increment of ammonia and nitrite levels, therefore catfish are able to grow better. Other water quality parameters did not show a specific relationship to $\mathrm{C} / \mathrm{N}$ ratio. In fact, it still needs more in-depth study to explain the correlation of water quality dynamics to the ratio $\mathrm{C} / \mathrm{N}$ in water and catfish growth.

\section{CONCLUSION}

The addition of molasses to increase water $\mathrm{C} / \mathrm{N}$ ratio up tol 4 to 21 could support the 


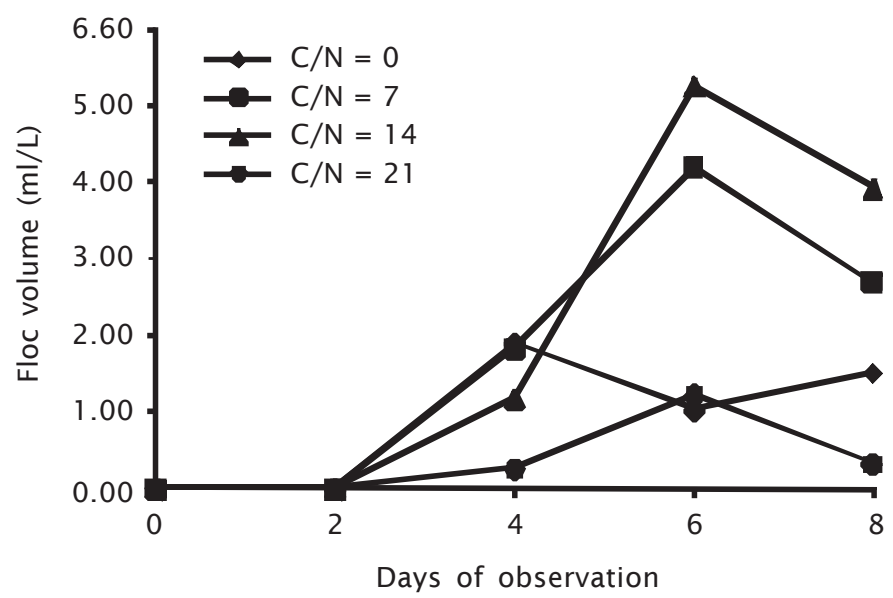

Figure 8. The dynamics of floc volume in the catfish culture water during eight days of observation

growth of heterotrophic bacteria and hindered the autotrophic nitrification process. It inhibited the increase of the levels of total ammonia and nitrite, therefore catfish grew faster.

\section{REFERENCES}

APHA. 2005. Standard Methods for the Examination of Water and Wastewater. $21^{\text {st }}$ Edition. Eaton, A.D., Clesceri, L.S., Rice, E.W., \& Greenberg, A.E. (Eds.). APHA, AWWA, and WEF. Washington, USA, p. 2-59.

Avnimelech, Y. \& Wyk, P.V. 2007. Bio-floc Technology: Principle and Application. Presentation in World Aquaculture 2007, AES Special Session: BIO floc Technology, February 28, 2007.San Antonio, Texas, USA.

Avnimelech, Y., Diab, S., Kochva, M., \& Mokady, S. 1992. Control and Utilization of inorganic nitrogen in intensive fish culture pond. Aquaculture and Fisheries Management, 23: 421-430.

Brune, D.E., Schwartz, G., Eversole, A.G., Collier, J.A., \& Schwedler, T.E. 2003. Intensification of pond aquaculture and high rate of photosynthetic systems. Aquacultural Engineering, 28: 65-86.

Bureau, D.P. 2004. Factors affecting metabolic waste outputs in fish. In: Suarez, C.L.E., Avances en Nutricion Acuicola VII. Memorias del VII Symposium Internacional de Nutricion Acuicola, 16-19 Noviembre, 2004. Hermosillo, Sonora, Mexico.

Crab, R., Avnimelech, Y., Defoirdt, T., Bossier, P., \& Verstraete, W. 2007. Nitrogen removal techniques in aquaculture for a sustainable production. Aquaculture, 270: 1-14.

Ebeling, J.M., Timmons, M.B., \& Bisogni, J.J. 2006. Engineering analysis of the stoichiometry of photoautotrophic, autotrophic, and heterotrophic removal of ammonia-nitrogen in aquaculture systems. Aquaculture, 257: 346-358.

Gross, A., Boyd, C.E., \& Wood, C.W. 2000. Nitrogen transformations and balance in channel catfish ponds. Aquacultural Engineering, 24: 1-14.

HACH. 2005. DR 2800 Spectrophotometer. Procedures Manual. November 2005 Edition 1. Hach Company. Germany, 816 pp.

McGraw, W.J. 2002. Utilization of heterotrophic and autotrophic bacteria in aquaculture. December 2002. Global Aquaculture Advocate, p. 82-83.

Montoya, R. \& Velasco, M. 2000. Role of bacteria on nutritional and management strategies in aquaculture systems. The Advocate, p. 35-36.

Schneider, O., Sereti, V., Eding, E.H., \& Verreth, J.A.J. 2005. Protein production by heterotrophic bacteria using carbonsupplemented fish waste. Presentation in World Aquaculture 2005. Bali, Indonesia (Abstract).

Schneider, O., Sereti, V., Machiels, M.A.M., Eding, E.H., \& Verreth, J.A.J. 2006. Producing potential of the heterotrophic bacteria biomass on aquaculture waste. Water Research, 40: 2,684-2,694. 
Schryver, P., Crab, R., Defoirdt, T., Boon, N., \& Verstraete, W. 2008. The basics of bio-flocs technology: The added value for aquaculture. Aquaculture, 277: 125-137.

Svobodová, Z., Lloyd, R., Máchová, J., \& Vykusová, B. 1993. Water quality and fish health. EIFAC Technical Paper. No. 54. Rome, FAO, $59 \mathrm{pp}$.
Wyk, P.V. \& Avnimelech, Y. 2007. Management of nitrogen cycling and microbial Populations in biofloc-based aquaculture systems. Presentation in World Aquaculture 2007, AES Special Session: BIO floc Technology, February 28, 2007.San Antonio, Texas, USA. 


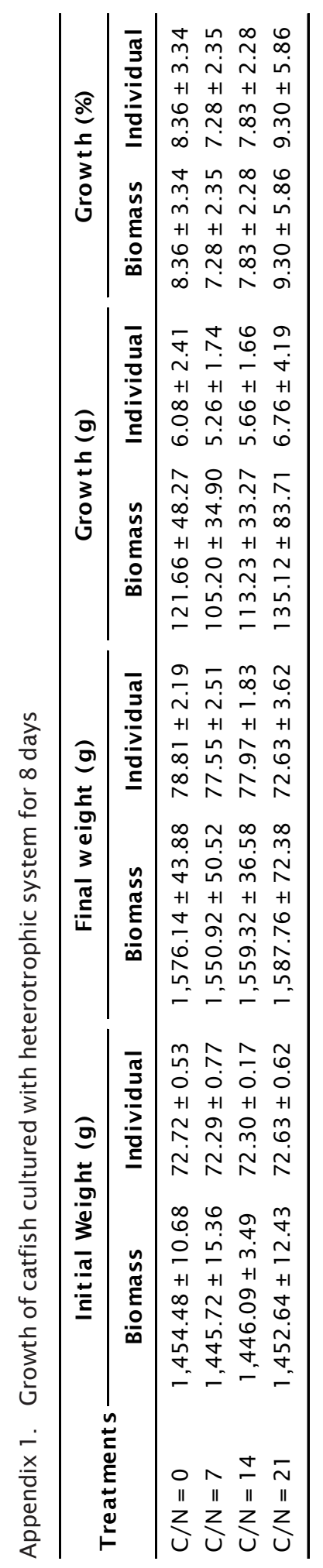

